\title{
Digital technologies for promotion of healthy eating habits in teenagers
}

\author{
Tecnologias digitais para promoção de hábitos alimentares saudáveis dos adolescentes \\ Tecnologías digitales para la promoción de hábitos alimentarios saludables de los adolescentes
}

\section{Caroline Magalhães de Alcântara' ORCID: 0000-0003-3898-0422}

Amanda Newle Sousa Silva' ORCID: 0000-0001-5728-847X

Patrícia Neyva da Costa Pinheiro" ORCID: 0000-0001-7022-8391

Maria Veraci Oliveira Queiroz' ORCID: 0000-0002-7757-119X

'Universidade Estadual do Ceará. Fortaleza-CE, Brasil. "Universidade Federal do Ceará. Fortaleza-CE, Brasil.

How to cite this article: Alcântara CM, Silva ANS, Pinheiro PNC, Queiroz MVO. Digital technologies for promotion of healthy eating habits in teenagers. Rev Bras Enferm. 2019;72(2):513-20. doi: http://dx.doi.org/10.1590/0034-7167-2018-0352

Corresponding Author:

Caroline Magalhães de Alcântara E-mail: caroline.magalhaes@aluno.uece.br

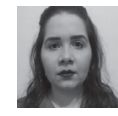

Submission: 05-27-2018

Approval: 08-23-2018

\section{ABSTRACT}

Objective: Identify and analyze the scientific literature on digital technologies for promotion of healthy eating habits in teenagers. Method: Integrative review of articles published in English and Spanish, available in full on four databases. The descriptors used were (Adolescent health) OR (Teen health) AND (Healthy diet) OR (Healthy eating) AND (Educational technology) OR (Instructional technology), respectively, from which eight articles were selected. Results: Among the studies included, three were digital games; two web-based nutrition interventions; two using online programs to prevent obesity; and one nutritional advice using multimedia. They showed experiences of digital technology and its effects on knowledge improvement and/or behavior of participants when developing healthy eating habits. Conclusion: Digital technologies are innovative tools present in the lives of teenagers, with the possibility of being used for education and promotion of healthy eating, contributing to the empowerment of the subject for his/her self-care.

Descriptors: Educational Technology; Health Promotion; Healthy Diet; Adolescent Health; School Nursing.

\section{RESUMO}

Objetivo: Identificar e analisar literatura científica sobre tecnologias digitais para promoção de hábitos alimentares saudáveis dos adolescentes. Método: Revisão integrativa de artigos publicados em inglês e espanhol, disponíveis na íntegra em quatro bases de dados. Foram utilizados os descritores (Adolescent health) OR (Teen health) AND (Healthy diet) OR (Healthy eating) AND (Educational technology) OR (Instructional technology), respectivamente, sendo selecionados oito artigos. Resultados: Dos estudos incluídos, foram três jogos digitais, duas intervenções nutricionais baseadas na Web; dois que utilizavam programas on-line de prevenção da obesidade e um aconselhamento nutricional com multimídia. Estes apresentavam experiências da tecnologia digital e seus efeitos na melhoria do conhecimento e/ou comportamento dos participantes na adesão a hábitos alimentares saudáveis. Conclusão: As tecnologias digitais são ferramentas inovadoras e presentes no cotidiano de adolescentes, com possibilidade de serem utilizadas para educação e promoção da alimentação saudável, contribuindo no empoderamento do sujeito para o seu cuidado.

Descritores: Tecnologia Educacional; Promoção da Saúde; Dieta Saudável; Saúde do Adolescente; Serviços de Enfermagem Escolar.

\section{RESUMEN}

Objetivo: Identificar y analizar la literatura científica sobre las tecnologías digitales para la promoción de hábitos alimentarios saludables de los adolescentes. Método: Revisión integrativa de los artículos que han sido publicados en inglés y en español, disponibles en su totalidad en cuatro bases de datos. Han sido utilizados los descriptores (Adolescent health) OR (Teen health) AND (Healthy diet) OR (Healthy eating) AND (Educational technology) OR (Instructional technology), respectivamente, habiendo sido seleccionados ocho artículos. Resultados: De los estudios incluidos, han sido tres juegos digitales, dos intervenciones nutricionales basadas en la Web; dos que utilizaban los programas en línea de prevención de la obesidad y un consejo nutricional con multimedia. Estos presentaban las experiencias de la tecnología digital y sus efectos en la mejora del conocimiento y/o el comportamiento de los participantes en la aceptación de hábitos alimentarios saludables. Conclusión: Las tecnologías digitales son herramientas novedosas y regalos en el cotidiano de adolescentes, con la posibilidad de ser utilizadas para la educación y la promoción de la alimentación saludable, contribuyendo en el empoderamiento del sujeto para su cuidado.

Descriptores: Tecnología Educacional; Promoción de la Salud; Dieta Saludable; Salud del Adolescente; Servicios de Enfermería Escolar. 


\section{INTRODUCTION}

Food and nutrition involves a set of economic, behavioral, cultural identity and social aspects that are decisive in the choice and consumption of healthy foods ${ }^{(1)}$. Understanding that social and family contexts influence inadequate eating habits and that the latter causes damage to health, it is observed that, in adolescence, the relationship between supply and consumption of healthy foods involves the autonomy of these youths to choose $\mathrm{e}^{(2)}$.

A Brazilian population-based study with 75000 teenagers aged between 12 and 17 years from 1,247 schools, distributed in 124 municipalities, pointed out that most of them eat "always or almost always" while watching television. The consumption of meals while performing entertainment activities results in the intake of large quantities of heavily caloric food, and teenagers prioritize the sodas, snack foods and candy instead of fruits at mealtime ${ }^{(3-4)}$.

This habit can be very harmful to the nutrition and overall health of adolescents, with repercussions in their adulthood, considering that they may acquire non-communicable chronic diseases, metabolic disorders, among other damages ${ }^{(4)}$. Therefore, in Brazil, a growing increase in overweight and obesity, malnutrition and micronutrient deficiencies is observed ${ }^{(5)}$. Among adolescents, the prevalence of obesity was $8.4 \%$; and of overweight, $17.1 \%{ }^{(6)}$.

The literature points several conditions of inadequate eating habits among teenagers ${ }^{(2-4)}$ and suggests the development of educational strategies that promote effective learning in health promotion, raising adolescents' awareness for a healthy eating ${ }^{(7)}$. In this sense, creative and ludic teaching resources provide adolescents with reflection and possibilities of empowering them to take care of themselves ${ }^{(1)}$.

The evidence is that adolescents, parents and teachers consider that the use of technology can be an instrument to practice healthy habits, because it proposes fun and improvement in the teenagers' self-esteem ${ }^{(8)}$. Health problems in adolescence resulting from inadequate nutrition and sedentarism require intense and propositional educational actions. Thus, the use of a digital game can encourage reflection on the importance of developing habits for the quality of life ${ }^{(9)}$.

Due to constant access and use of digital technologies by teenagers, these tools can be a means for educating this public regarding healthy habits, enabling learning and interests in the dissemination of information about the topic ${ }^{(10)}$. The wide use of means of communication among adolescents facilitates the access to new knowledge about food and nutrition during their free time ${ }^{(10)}$.

Thus, the frequent use of devices with access to internet by teenagers has motivated changes in the teaching and learning process, favoring the development of active and critical individuals $^{(11)}$. In health, the use of new methods and educational technologies enable autonomy in the students' learning process, which produces relevant impact on care provision ${ }^{(12)}$.

Stressing that nurse is a health educator and uses digital technologies as tools to support teaching, through discussion, debate, reflection and exchange of experiences, facilitating the planning of care is important ${ }^{(13)}$. The nurse uses effective distance education strategies for teaching-learning of the individual in the care of themselves, offers of the knowledge acquisition and the exercise of his/her autonomy because, currently, there is constant need of search for information with educational purposes. To that end, different learning models, which change in different contexts of action, are made ${ }^{(14)}$.

Therefore, since the promotion of healthy eating brings health impacts and that, among teens, inadequate eating habits are frequent, this study aimed to identify scientific evidences on digital technologies for promotion of healthy eating habits, understanding that the nurse, in his/her professional action, engages in educational activities with this public to stimulate, more and more, the use of innovative methods and resources in which teenagers are interested.

In this context, digital technologies are considered a type of educational support that can broaden adolescents' knowledge on eating habits and, thus, help them actively in their choices. Thereby, this study is relevant to support the creation and use of digital technology in the promotion of healthy eating.

\section{OBJECTIVE}

Digital technologies for promotion of healthy eating habits in teenagers

\section{METHOD}

This is an integrative literature review, gathering findings of studies with different methodologies, which allow reviewers to analyze and summarize primary data in a systematic and rigorous manner ${ }^{(15)}$. This study consisted of six steps: 1 ) elaboration of the research question; 2 ) search for primary studies in literature based on inclusion and exclusion criteria; 3 ) organization of preselected studies (data extraction of studies); 4) critical analysis of the studies selected; 5) summary of results; and 6) presentation of integrative review ${ }^{(16)}$.

The development of research was based on the following question: What are the digital technologies available for the promotion of healthy eating habits in teenagers? For the elaboration of the research question, we used the PICo mnemonic strategy (Population: teenagers; Action: use of educational digital technologies; Context: digital technologies for the promotion of healthy eating habits). Since this study was not aimed to compare interventions or verify their results, the elements $C$ and $O$ were not used; however, the context was used, which is recommended in this type of study ${ }^{(16)}$.

The selection of studies occurred from January to March 2018 in the following databases: National Library of Medicine National Institutes of Health (PubMed), Cumulative Index to Nursing and Allied Health Literature (CINAHL), Latin American and Caribbean Health Sciences Literature (LILACS) and Web of Science.

The terminology used for the search was based on the Medical Subject Headings (MESH) and on the Health Sciences Descriptors (DECS). Each controlled descriptor from PICo element was cross-correlated with its non-controlled descriptor using the Boolean operator AND between the non-controlled descriptors, the crossing through the Boolean operator OR, resulting in the following cross-correlation: (Adolescent health) OR (Teen health) AND (Healthy diet) OR (Healthy eating) AND (Educational technology) OR (Instructional technology). 
The processes of search and analysis of the studies were carried simultaneously out by two researchers, aiming at study validation. The inclusion criteria applied were: primary studies; Portuguese, English and Spanish languages. The exclusion criteria were: editorials; review studies; case studies; and studies duplicated in the databases, totalling 2,836 studies. The period of study was not delimited to encompass the largest possible number of studies, because, even with the increasing technological advancement, the older media such as compact discs (CDs) demonstrate contribution to the promotion of healthy eating and the practice of physical activity.

The selection of studies occurred by reading the titles and abstracts and, when this reading was not enlightening, the texts were read in full. Thus, 77 articles were obtained, from which, after reflective reading, and 8 articles comprised the sample. The 4 steps of the review are summarized in Figure 1, using the tool Preferred Reporting Items for Systematic Review and Meta-Analyses (PRISMA) ${ }^{(17)}$.

For data collection, we used an instrument ${ }^{(18)}$ adapted for organizing and summarizing the studies, shown in the summary table. The variables were: first author, year, country, title, type of study, and contributions to the teenagers. The analysis proceeded with the reading of the articles selected, which were described, promoting synthesis and discussion of the knowledge produced.

\section{RESULTS}

The eight studies belonged to three databases; one from MEDLINE/ PubMed, one from Web of Science and six from CINAHL, all written in English. The years of publication were: 2 in 2004; 4 in 2013; 2 in 2016. As shown in Chart 1, the country of origin of most of them were the United States, with 6 articles; and Italy and France with 1 article each.

Different types of digital technologies were found: Gustave in Gnam's planet $^{(19)}$, interactive CD-ROM (SyberShop) ${ }^{(20)}$, interactive kiosk game (Nutri-Advice) (21), two obesity prevention programs (HEALTH [and] TEEN and Coping Skills Training) on a website, each one of these two having different studies ${ }^{(9,22)}$, website (Teen Choice: Food and Fitness) (23), Serious Game (Creature-101)(24), and one web-based nutritional intervention ${ }^{(25)}$. All of them involved technologies with multimedia access, and only one did not require internet. Two had more than ten years of publication, the others had two and five years of publication. Only one of the studies was not conducted in the school environment. The studies presented the experience of applying the technology and the effects of the devices tested, improving knowledge and/or changing the participants' behavior when choosing healthy foods.

Thus, all studies showed the participants' learning, and two associated food education with the control of obesity. These technologies provided the adolescents with nutritional counseling, encouraged by the multidisciplinary team. Among them, four studies were conducted by nutritionists, three by nurses and one by doctors and psychologists.
The studies were described and listed in Chart 1. The first study used SyberShop ${ }^{(20)}$, a CD with five modules (Virtual Food Court, Virtual Cafeteria, Blocks of Construction, Body Dimensions and Be Active), which could be browsed in 45 minutes (of each module) and were used by teachers in their classes as additional support, individually or in group of teenagers. In addition, the class included feedback from teenagers and were aimed at educating with fun and overcoming challenges, instigating the participants.

In the second study ${ }^{(25)}$, two groups were compared: the first did not have computers with internet access and had nutritional education incorporated into the school curriculum for one month. The second intervention group had computers with internet access with 5 hours of web-based nutrition education and 10 hours of academic load. The content of the intervention group was divided into three modules: "Treasure hunt: a search for the Golden Orb", "Demonstrator: coffee of Ruby " and "WebQuest: Diet and Long Health", available on an educational site, had instructions, educational objectives and interactive questions suit for adolescents.

The third study compared the effectiveness of two programs in the school HEALTH [and] TEEN and HEALTH [and] TEEN + Coping Skills Training (CST) $)^{(9)}$ for obesity prevention through the interactive digital environment (internet) and provided behavioral support for the adoption of healthy eating and the practice of physical activity, aiming at reducing overweight and obesity in adolescents. The HEALTH [and] TEEN program was the only whose main components were lessons, goal setting, self-monitoring, training and social media. They were distributed into eight interactive lessons. At the end, students received individual feedback through self-evaluations and reflections on the contents. The themes of these lessons were nutrition, physical activity, metabolism and control of food portions. The other program 
Chart 1 - Presentation of the studies included in the study, Brazil, 2004-2016

\begin{tabular}{|c|c|c|}
\hline $\begin{array}{c}\text { First author, Year, Coun- } \\
\text { try and Title }\end{array}$ & Type of study & $\begin{array}{c}\text { Contribution of the } \\
\text { study to the promotion } \\
\text { of healthy habits in } \\
\text { teenagers }\end{array}$ \\
\hline $\begin{array}{l}\text { 1. Dunn, C. 2004. North } \\
\text { Carolina, USA. SyberShop: } \\
\text { Digital Solutions for } \\
\text { Eating Healthy and Being } \\
\text { Active }^{(20)} \text {. }\end{array}$ & $\begin{array}{l}\text { Methodological } \\
\text { research }\end{array}$ & $\begin{array}{l}\text { The use of Sybershop } \\
\text { contributed to the } \\
\text { promotion of healthy } \\
\text { eating and practice of } \\
\text { physical activity. }\end{array}$ \\
\hline $\begin{array}{l}\text { 2. Long, J.D. 2004. Texas, } \\
\text { EUA. Using Technology } \\
\text { to Promote Self-Efficacy } \\
\text { for Healthy Eating in } \\
\text { Adolescents }{ }^{(25)} \text {. }\end{array}$ & $\begin{array}{l}\text { Quasi- } \\
\text { experimental } \\
\text { study. }\end{array}$ & $\begin{array}{l}\text { The use of web provided } \\
\text { nutrition education for } \\
\text { teenagers, helping them } \\
\text { promote self-efficacy for } \\
\text { a healthy diet. }\end{array}$ \\
\hline $\begin{array}{l}\text { 3. Whittemore, R. } \\
\text { 2013. Connecticut, EUA. } \\
\text { An Internet Obesity } \\
\text { Prevention Program for } \\
\text { Adolescents }{ }^{(9)} \text {. }\end{array}$ & $\begin{array}{l}\text { Randomized } \\
\text { Clinical Trial }\end{array}$ & $\begin{array}{l}\text { The use of the } \\
\text { intervention with the } \\
\text { programs HEALTH } \\
\text { [and] TEEN + Coping } \\
\text { Skills Training showed } \\
\text { improvement in } \\
\text { sedentary and nutrition } \\
\text { behavior, physical } \\
\text { activity, self-efficacy and } \\
\text { satisfaction. }\end{array}$ \\
\hline $\begin{array}{l}\text { 4. Whittemore, R. } \\
\text { 2013. Connecticut, } \\
\text { EUA. Implementation } \\
\text { of a School-based } \\
\text { Internet Obesity } \\
\text { Prevention Program } \\
\text { for Adolescents }{ }^{(22)} \text {. }\end{array}$ & $\begin{array}{l}\text { Mixed } \\
\text { methods, } \\
\text { clinical trial }\end{array}$ & $\begin{array}{l}\text { Evaluation of the } \\
\text { reach, adoption and } \\
\text { implementation of } \\
\text { HEALTH [and] TEEN for } \\
\text { promoting healthy eating } \\
\text { and practice of physical } \\
\text { activity; contributed to a } \\
\text { lesser weight increase in } \\
\text { adolescents. }\end{array}$ \\
\hline $\begin{array}{l}\text { 5. Cullen, K.W. } 2013 \text {. } \\
\text { Houston, EUA. Evaluation } \\
\text { of a web-based program } \\
\text { promoting healthy eating } \\
\text { and physical activity for } \\
\text { adolescents: Teen Choice: } \\
\text { Food and Fitness }{ }^{(23)} \text {. }\end{array}$ & $\begin{array}{l}\text { Randomized } \\
\text { Clinical Trial }\end{array}$ & $\begin{array}{l}\text { The technology Teen } \\
\text { Choice (website) } \\
\text { improved fruit and } \\
\text { vegetable intake as } \\
\text { well reduced sedentary } \\
\text { behavior. }\end{array}$ \\
\hline $\begin{array}{l}\text { 6. Majumdar, D. } \\
\text { 2013. Nova York, EUA. } \\
\text { "Creature-101": A Serious } \\
\text { Game to Promote } \\
\text { Energy Balance-Related } \\
\text { Behaviors Among Middle } \\
\text { School Adolescents }\end{array}$ & $\begin{array}{l}\text { Intervention } \\
\text { study }\end{array}$ & $\begin{array}{l}\text { Evaluation of the } \\
\text { effectiveness of the } \\
\text { Serious game: promotion } \\
\text { of healthy eating and } \\
\text { physical activity with } \\
\text { reduction in the intake } \\
\text { of processed snacks, } \\
\text { in the consumption of } \\
\text { sweetened beverages and } \\
\text { in the recreational screen } \\
\text { time were observed. }\end{array}$ \\
\hline $\begin{array}{l}\text { 7. Fraticelli, F. } 2016 . \\
\text { Italy. Technology-based } \\
\text { intervention for healthy } \\
\text { lifestyle promotion in } \\
\text { Italian adolescents }{ }^{(19)} \text {. }\end{array}$ & Clinical trial & $\begin{array}{l}\text { The game Gustave in } \\
\text { Gnam's planet promoted } \\
\text { knowledge about } \\
\text { healthy nutrition and } \\
\text { analysis of fun. }\end{array}$ \\
\hline $\begin{array}{l}\text { 8. Turnin, M.C. } 2016 . \\
\text { France. Effect of } \\
\text { Nutritional Intervention } \\
\text { on Food Choices of } \\
\text { French Students in Middle } \\
\text { School Cafeterias, Using } \\
\text { an Interactive Educational } \\
\text { Software Program (Nutri- } \\
\text { Advice)(21). }\end{array}$ & $\begin{array}{l}\text { Quasi- } \\
\text { experimental } \\
\text { study. }\end{array}$ & $\begin{array}{l}\text { The use of nutritional } \\
\text { counseling allowed } \\
\text { change in choice of } \\
\text { foods and weight } \\
\text { reduction during the } \\
\text { intervention period. }\end{array}$ \\
\hline
\end{tabular}

included all components of HEALTH [and] TEEN and more four lessons on coping skills to address psychosocial challenges of healthy eating and physical activity, such as resolution of social problems, decrease in stress, positive communication and conflict resolution. Behavioral strategies for self-monitoring and goal setting activities included a blog comprised of a health coach, holding a nursing degree, as a way to interact with the professional and other students.

In the fourth study ${ }^{(22)}$, the authors evaluated the reach, adoption and implementation of the HEALTH [and] TEEN program in different environments - in the classroom and when doing homework. One could observe that teenagers who used the technology in school had more success in adopting healthy behaviors than those who used it at home. The teachers made positive comments regarding the content of the program and website functionality. The students needed to be able to complete the program online at their own pace and have the ability to interact with one another.

The fifth study brought the technology Teen Choice: Food and Fitness ${ }^{(23)}$ (website), with the purpose of testing the impact of the website on the promotion of nutrition and the practice of physical activity. The teenagers were recruited through health fairs, schools, churches, community organizations, newspaper, radio and advertisements. The students from the intervention group reported eating three or more daily portions of vegetables in the week before the filling out of the questionnaire, confirming the effectiveness in improving the habits.

The sixth study, with the game Serious Game-Criature 101(24), dealt with the promotion of healthy eating and the practice of physical activity in a single intervention. The activities occurred two to three times a week for one month, having four levels. In level I, students learned about the purpose of the game; in level $\mathrm{II}$, they learned about the importance of the intake of water, fruits and vegetables and the practice of physical activity; in level III, they began to analyze their own behavior and set personal goals to be achieved; and, in level IV, students presented the energy balance of their character represented in the game, talked about the progress of the objectives they set and about how the game contributed to their health. During the intervention period, they reported a greater adoption of the dietary recommendations compared with the control group.

The seventh study used Gustave in Gnam's planet ${ }^{(19)}$, game developed to help students learn about healthy eating and physical activity and to prevent obesity and type 2 diabetes mellitus. It has three different steps: the evaluation and a link to connection to the two games on the web, Angry Birds Halloween and Gustave in Gnam's planet. Each teenager participated in three sessions to perform all the activities. In the first week, they filled the intake measures, then played Angry Birds Halloween; in the second week, they filled the intake measures again and played Gustave in Gnam's planet; and, in the third week, they only made the measurement.

The eighth technology, called interactive kiosk (Nutri-Advice)(21), is a software of the program, which consist of interactive computer terminals (kiosks), developed in Diabetology on and Nutrition Department of the Toulouse University Hospital; It was tested in teenagers in schools to encourage the choice of healthy foods.

Digital technologies showed different forms to be used, and their results were satisfactory regarding the participants'learning. 


\section{DISCUSSION}

Digital technologies provide teenagers with several possibilities of interaction among peers, access to resources of varied interests, and can be used for health promotion. The use of these tools by them offers distance learning and education, facilitating the process of knowledge construction ${ }^{(14)}$. The authors ${ }^{(14,19)}$ point out that these technologies can be effective for use in multidimensional education programs for prevention of diseases and health promotion for helping on the difficulties faced through the achievement of goals by means of individuals' interaction and entertainment.

Digital technology with the purpose of teaching and better adherence to a healthy lifestyle must have the participants' collaboration in the process, paying attention to the different contexts of the individuals involved ${ }^{(21)}$. For this purpose, creative and ludic learning resources are those using dynamism and socialization, providing individual's dialogue, reflection and possibilities of empowerment. Furthermore, the wide use of means of communication among adolescents facilitates the access to new knowledge about food and nutrition during their free time ${ }^{(10)}$.

Thus, digital technologies are possibilities of learning to address the topic "health", and the virtual entertainments can be incorporated into the educational process. In another study, the authors concluded that virtual environments are powerful means of education for healthy eating, since they are the most used by teenagers and capture their attention the most. Thus, they can be used for school or after-school activities, changing these people's lifestyle by being implemented with the use of minimal resources ${ }^{(24)}$.

The debate about healthy eating is a reality among educators and is transversally present in the everyday life of health professionals and school, to empower the teenagers regarding their knowledge about the subject, promoting changes in habits. The study shows that nutrition is related to socioeconomic and cultural conditions and that the orientations for adolescents in their social environment can improve food choices ${ }^{(26)}$.

However, even the teenagers being motivated to have positive changes in their eating habits, inadequate choice and sedentary lifestyle are clearly observed in their everyday life, considering more than 3 hours per day spent in front of the television, physical inactivity and preference for industrial or high-calorie products instead of healthy meals, contributing to the increased prevalence of overweight in this public ${ }^{(27)}$.

In Brazil, several school programs aim to prevent obesity and overweight in children and adolescents; however, the implementation of the actions poses many limitations ${ }^{(28)}$. Even with the existence of some technologies focused on the prevention of obesity in adolescents, other innovations, which use their social environment, are needed, because these devices reach a larger public, attract the most attention and promote knowledge, clarification of doubts, desire to learn and reflection about the subject ${ }^{(29)}$.

The online programs for obesity prevention implemented in school usually standardizes their contents, but this study ${ }^{(30)}$ shows the implementation of the program in the school environment is complex, because it encompasses many factors, such as the configuration for its insertion, age of student, teacher's characteristics and his/her way of teaching. In addition, the factors that may influence the participation and satisfaction of students must be considered, as well as the results of the online obesity prevention program, involving academic performance, the way in which the student prefer to learn and his/her motivation. The authors $^{(30)}$ paid attention to the fact that the use of these technologies by teenagers need to be controlled because it has created many challenges for the education of this generation, once the use of the internet have meanings and effects concerning the development in this life stage.

Of the studies selected, three were games ${ }^{(19,23-24)}$, designed for promoting knowledge and encouraging the adoption and maintenance of healthy eating habit in teenagers. A study shows the purpose of the games presented on the web was to stimulate learning and greater interaction among peers, favoring the adherence to healthy habits and improvements not only in relation to the weight, but also to physical, mental and emotional health ${ }^{(31)}$. Therefore, the technologies must be adapted to the teenagers' experiences and widely used in leisure activities and school, because fun and interaction has proven to be an innovative and beneficial method of nutritional education for adolescents, preventing chronic diseases and obesity ${ }^{(25)}$.

In addition, digital games emerge with the aim of breaking the existing barriers in schools - such as lack of inputs and materials available to develop the activities - and supply, also, the lack of personnel and time available to implement educational activities ${ }^{(24)}$.

The authors ${ }^{(8)}$ state that the use of games is very prized by teenagers both individually and collectively, because they can get away from routine and immerse in an environment in which they will be protagonists of their stories. In addition, a competition between teenagers will be stimulated to know who the best player is.

Another strategy used to promote healthy eating and physical movement is the use of exergames, for adolescents use movementbased video games to increase energy expenditure. However, social interaction is fundamental for the teenager to have more effective behavior changes, since he/she will be motivated to acquire healthy eating habits ${ }^{(32)}$.

The use of digital technologies in education has been challenging, because educators have found difficulties in using it. Among these difficulties, the poor conditions of the computer lab and internet access can be highlighted. Students also mentioned the difficulties of group work, because not all the members are cooperative, which hinders the completion of the activities ${ }^{(11,33)}$. There are many debates about effects of the excessive use of digital technologies by teenagers, emerging questions about its benefits and harms to the psychosocial and emotional development ${ }^{(34)}$.

Nevertheless, one discusses the advantages of using multimedia devices in food education and prevention of diseases, because these educational programs reach a larger public and are attractive and affordable tools. However, the recommendation is to value classroom teaching as an important teaching strategy. Thus, the technology based on teenagers' actual experiences and knowledge allowed customized nutritional counseling and right choice of their daily diet - both the language and the use of the software were easy to understand. Using this tool allowed observing the importance of the individuals' autonomy when choosing healthy habits ${ }^{(21)}$. The changes in teenagers' attitudes are instigated by reflections and learnings in the midst of interactions and entertainment. 
Another point mentioned is that social media has direct influence over teenagers who are connected to technologies and interfere directly in their habits and behaviors, especially nutritional. The influence exerted by the group, in fact, serves to cushion this problem and even leads to a better quality of life and reeducation; however, individual interventions may fail(35).

Digital technologies can assist the multidisciplinary team in helping the teenager to take care of himself/herself, by the teaching-learning process, turning him/her into an independent person and empowering him/her for decision-making ${ }^{(36)}$. Actions of this type, implemented in an interdisciplinary manner, contribute to the rescue of the overview and integrality of care for adolescents ${ }^{(37)}$. However, gaps of integral care aimed at this public and difficulties in inserting it into health promotion actions ${ }^{(28)}$, according to the Brazilian National Policy on Food and Nutrition (PNAN) ${ }^{(5)}$, are observed.

Descriptive study on the practice of health education using webquest and blog in the promotion of healthy eating with teenagers favored the search for participatory and active knowledge, besides promoting an area of integration of health professionals into the school environment. However, training of teachers and of all school employees is important, noting the possibilities of technology as a teaching strategy, and inserting the student at the core of the learning process and teachers and/or other professionals as mediators who encourage the use of technology as teaching strategy ${ }^{(33)}$.

When caring for adolescents, the nurse naturally must take the role of educator and health promoter. In this process, this professional must seek innovative and attractive strategies that are part of the everyday life of these youths, based on scientific evidences capable of providing comprehensive care ${ }^{(38)}$. In this respect, the use of digital technologies can provide adolescents with education about the topic, as well as with fun, interaction and universal access. This purpose of meaningful learning can motivate them to choose healthy food.

\section{Study limitations}

All the studies from the databases used addressed digital technologies in the promotion of habits and healthy eating with adolescents; the studies were conducted abroad, in the United States, France and Italy, and none of the articles from Brazil focused on this theme or answered the research question. Therefore, the limitation is associated with this search, which, if expanded, could find national realities and evidences on the use of this tool as support in the promotion of healthy eating habits.

\section{Contributions of the study}

The topic of healthy eating in adolescents has been the agenda of public policies in the country to reduce the indices of diseases dependent on modifiable behaviors. Thus, the results bring answers to inquiries from researchers and insights for the development of studies in nursing and in health with the creation of educational technologies and assessment of their impact on adolescents, contributing to policies for proper and healthy nutrition and eating habits.

\section{CONCLUSION}

Most of the studies using digital technologies for the promotion of healthy eating habits in teenagers were associated with physical activity and showed improved knowledge and/ or behavior of participants in the adoption of these habits. The experimental studies have confirmed the effectiveness of the intervention with use of digital technology for the promotion of healthy dietary practice.

Thus, the scientific evidences found can support the development of technologies intended for the teenager on education of healthy habits, with positive impacts on nurse's clinical practice, which - in conjunction with the work of other professionals of health, education and family - can change attitudes to improve adolescents' health and quality of life. To this end, observing interests, preferences, and cultural context in the development and implementation of these technologies is essential.

Then, digital technologies are innovative tools present in teenagers' lives and can be used for education and promotion of healthy eating, contributing to the empowerment of the individual in his/her self-care.

\section{REFERENCES}

1. Lima RS, Ferreira Neto JA, Farias RCP. Alimentação, comida e cultura: o exercício da comensalidade. Demetra. 2015;10(3):507-22. doi: https:// doi.org/10.12957/demetra.2015.16072

2. Oliveira CC, Costa TMB, Laus MF. Hábitos alimentares e comportamentos inadequados para controle de peso em adolescentes frequentadores de academias de ginástica. Adolesc Saude [Internet]. 2012[cited 2018 Jul 31];9(3):47-55. Available from: http://www. adolescenciaesaude.com/detalhe_artigo.asp?id=330

3. Barufaldi LA, Abreu GZ, Oliveira JS, Santos DF, Fujimori E, Vasconcelos SML, et al. ERICA: prevalência de comportamentos alimentares saudáveis em adolescentes brasileiros. Rev Saude Publica. 2016;50(supl-):6s.

4. Oliveira JS, Barufaldi LA, Abreu GA, Leal VA, Brunken GS, Vasconcelos SML, et al. ERICA: uso de telas e consumo de refeições e petiscos por adolescentes brasileiros. Rev Saúde Pública. 2016;50 Suppl 1:S1-9. doi: http://dx.doi.org/10.1590/S01518-8787.2016050006680

5. Ministério da Saúde (BR). Secretaria de Atenção à Saúde. Departamento de Atenção Básica. Marco de referência da vigilância alimentar e nutricional na atenção básica. Brasília: MS; 2015.

6. Bloch KV, Klein CH, Szklo M, Kuschnir MCC, Abreu GA, Barufaldi LA, et al. ERICA: prevalências de hipertensão arterial e obesidade em adolescentes brasileiros. Rev Saude Publica. 2016;50 Suppl 1:S1-13. doi: http://dx.doi.org/10.1590/S01518-8787.2016050006685 
7. Costa CS, Flores TR, Wendt A, Neves RG, Assunção MCF, Santos IS. Comportamento sedentário e consumo de alimentos ultraprocessados entre adolescentes brasileiros: Pesquisa Nacional de Saúde do Escolar (PeNSE), 2015. Cad Saúde Pública [Internet]. 2018 [cited 2018 Jul 31];34(3):e00021017. Available from: http://www.scielo.br/pdf/csp/v34n3/1678-4464-csp-34-03-e00021017.pdf

8. Carrion C, Moliner LA, Castell C, Puigdomènech E, Gómez SF, Domingo L, et al. Utilización del teléfono móvil para el fomento de hábitos saludables en adolescentes: estudio con grupos focales. Rev Esp Salud Pública [Internet]. 2016[cited 2018 Jul 31];90(Esp):1-11. Available from: http://scielo.isciii.es/pdf/resp/v90/1135-5727-resp-90-e40022.pdf

9. Whittemore R, Jeon S, Grey M. An Internet Obesity Prevention Program for Adolescents. J Adolesc Health. 2013;52(4);439-47. doi: http:// dx.doi.org/10.1016/j.jadohealth.2012.07.014

10. Pereira TS, Pereira RC, Angelis-Pereira MC. Influência de intervenções educativas no conhecimento sobre alimentação e nutrição de adolescentes de uma escola pública. Ciênc Saúde Colet [Internet]. 2017[cited 2017 Dec 17];22(2):427-35. Available from: http:// www.scielo. $\mathrm{br} / \mathrm{pdf} / \mathrm{csc} / \mathrm{v22n2/1413-8123-csc-22-02-0427.pdf}$

11. Bittencourt PAS, Albino JP. O uso das tecnologias digitais na educação do século XXI. Rev Ibero-Am Estud Educ. 2017;12(1):205-14. doi: https://doi.org/10.21723/riaee.v12.n1.9433

12. Thukral A, Joshi M, Joshi P, Prakash V, Adkoli BV, Deorari AK. Apps for management of sick newborn: evaluation of impact on health care professionals. J Trop Pediatr. 2014;60(5):370-6. doi: http://dx.doi.org/10.1093/tropej/fmu032

13. Aragão JMN, Gubert FA, Torres RAM, Silva ASR, Vieira NFC. The use of Facebook in health education: perceptions of adolescent students. Rev Bras Enferm[Internet]. 2018[cited 2018 Jul 31];71(2):265-71. Available from: http://www.scielo.br/pdf/reben/v71n2/pt_0034-7167reben-71-02-0265.pdf

14. Tavares APC, Leite BS, Silveira IA, Santos TD, Brito WAP, Camacho ACLF. Analysis of Brazilian publications on distance education in nursing: integrative review. Rev Bras Enferm [Internet]. 2018[cited 2018 Jul 31];71(1):214-22. Available from: http://www.scielo.br/pdf/reben/v71n1/ pt_0034-7167-reben-71-01-0214.pdf

15. Soares CB, Hoga LAK, Peduzzi M, Sangaleti C, Yonekura T, Silva DRAD. Revisão integrativa: conceitos e métodos utilizados na enfermagem. Rev Esc Enferm USP [Internet]. 2014[cited 2018 Apr 23];48(2):335-45. Available from: http://www.scielo.br/pdf/reeusp/v48n2/pt_0080-6234reeusp-48-02-335.pdf.

16. Botelho LLR, Cunha CCA, Macedo M. O método da revisão integrativa nos estudos organizacionais. Gestao Soc [Internet]. 2011 [cited 2013 Aug 18];5(11):121-36. Available from: http://www.gestaoesociedade.org/gestaoesociedade/article/view/1220.

17. Galvão TF, Pansani TSA, Harrad D. Principais itens para relatar revisões sistemáticas e Meta-análises: a recomendação PRISMA. Epidemiol Serv Saúde [Internet]. 2015[cited 2018 Apr 18];24(2):335-42. Available from: http://www.scielosp.org/pdf/ress/v24n2/2237-9622ress-24-02-00335.pdf

18. Ursi ES, Galvão CMM. Prevenção de lesões de pele no perioperatório: revisão integrativa da literatura. Rev Latino-Am Enfermagem [Internet]. 2006[cited 2018 Apr 23];14(1):124-31. Available from: http://www.scielo.br/pdf/rlae/v14n1/v14n1a17.pdf.

19. Fraticelli F, Marchetti D, Polcini F, Mohn AA, Chiarelli F, Fulcheri M, et al. Technology-based intervention for healthy lifestyle promotion in Italian adolescents. Ann Ist Super Sanità. 8 de janeiro de 2016;52(1):123-7.

20. Dunn C, Thomas C, Greene C, Pegram L. SyberShop: digital Solutions for eating healthy and being active. J Nutr Educ Behav. 2004;36(6):3312. doi: https://doi.org/10.1016/S1499-4046(06)60405-3

21. Turnin MC, Buisson JC, Ahluwalia N, Cazals L, Bolzonella-Pene C, Fouquet-Martineau C, et al. Effect of nutritional intervention on food choices of French students in middle school cafeterias, using an interactive educational software program (Nutri-Advice). J Nutr Educ Behav. 2016 fev; 48(2):131-7. doi: http://dx.doi.org/10.1016/j.jneb.2015.09.011

22. Whittemore R, Chao A, Jang M, Jeon S, Liptak T, Popick R, et al. Implementation of a school-based internet obesity prevention program for adolescents. J Nutr Educ Behav. 2013;45(6):586-94. doi: http://dx.doi.org/10.1016/j.jneb.2013.03.012

23. Cullen KW, Thompson D, Boushey C, Konzelmann K, Chen T. Evaluation of a web-based program promoting healthy eating and physical activity for adolescents: teen choice: food and fitness. Health Education Research. 2013;28(4):704-14. doi: http://dx.doi.org/10.1093/her/cyt059

24. Majumdar D, Koch PA, Lee H, Contento IR, Islas-Ramos AL, Fu D. “Creature-101”: a serious game to promote energy balance-related behaviors among middle school adolescents. Games Health J. 2013;2(5):280-90. doi: http://dx.doi.org/10.1089/g4h.2013.0045

25. Long JD, Stevens KR. Using technology to promote self-efficacy for healthy eating in adolescents. J Nurs Scholarsh, 2004;36(2):134-9.

26. Becker AE, Fay KE, Agnew-Blais J, Khan AN, Striegel-Moore RH, Gilman SE. Social network media exposure and adolescent eating pathology in Fiji. Br J Psychiatry. 2011;198(1):43-50.

27. Wendpap LL, Ferreira MG, Rodrigues PRM, Pereira RA, Loureiro AS, Gonçalves-Silva RMV. Qualidade da dieta de adolescentes e fatores associados. Cad Saúde Pública [Internet]. 2014[cited 2018 Jul 02];30(1):97-106. Available from: http://www.scielo.br/pdf/csp/v30n1/0102311X-csp-30-01-00097.pdf.

28. Brasil EGM, Silva RM, Silva MRF, Rodrigues DP, Queiroz MVO. Adolescent health promotion and the School Health Program: complexity in the articulation of health and education. Rev Esc Enferm USP[Internet]. 2017[cited 2018 Apr 23];51:e03276. Available from: http://www. scielo.br/pdf/reeusp/v51/en_1980-220X-reeusp-S1980-220X2016039303276.pdf

29. Smith JJ, Morgan PJ, Plotnikooff RC, Dally KA, Salmon J, Okely AD, et al. Smart-phone obesity prevention trial for adolescent in low-income communities: the ATLAS RCT. Pedriatrics[Internet]. 2014[cited 2018 Apr 23];134(3);723-31. Available from: http://pediatrics.aappublications. 
org/content/134/3/e723

30. Spizzirri RCP, Wagner A, Mosmann CP, Armani AB. Adolescência conectada: mapeando o uso da internet em jovens internautas. Psicol Argum[Internet]. 2012[cited 2018 Apr 23];30(69):327-35. Available from: https://periodicos.pucpr.br/index.php/psicologiaargumento/ article/view/23288

31. Bravender T, Tulsky JA, Farrell D, Alexander SC, Ostbye T, Lyna P, et al. Teen CHAT: development and utilization of a web-based intervention to improve physican communication with adolescents about healthy weight. Patient Educ Couns. 2013;93(3):525-31. doi: http://dx.doi. org/10.1016/j.pec.2013.08.017

32. Calvert SL, Staiano AE, Bond BJ. Eletronic gaming and the obesity crisis. New Dir Child Adolesc Dev. 2013;2013(139):51-7. doi: http://dx.doi. org/10.1002/cad.20031

33. Czerwinski GPV, Cogo ALP. Webquest e blog como estratégias educativas em saúde escolar. Rev Gaúcha Enferm. 2018;39:e2017-0054. doi: http://dx.doi.org/10.1590/1983-1447.2018.2017-0054

34. Silva TO, Silva LTG. Os impactos sociais, cognitivos e afetivos sobre a geração de adolescentes conectados às tecnologias digitais. Rev Psicopedag[Internet]. 2017[cited 2018 Jul 31];34(103):87-97. Available from: http://pepsic.bvsalud.org/pdf/psicoped/v34n103/09.pdf

35. Zhang J, Tong L, Lamberson PJ, Durazo-Arvizu RA, Luke A, Shoham DA. Leveraging social influence to address overweight and obesity using agent-based models: the role of adolescent social networks. Soc Sci Med. 2015;125(2015):203-13. doi: http://dx.doi.org/10.1016/j. socscimed.2014.05.049

36. Silva KVLG, Gonçalves GAA, Santos SB, Machado MFAS, Rebouças CBA, Silva VM, et al. Training of adolescent multipliers from the perspective of health promotion core competencies. Rev Bras Enferm. [Internet]. 2018 Feb [cited 2018 Jul 31];71(1):89-96. Available from: http://www.scielo.br/pdf/reben/v71n1/0034-7167-reben-71-01-0089.pdf

37. Medeiros AC, Siqueira HCH, Zamberlan C, Cecagno D, Nunes SS, Thurow MRB. Comprehensiveness and humanization of nursing care management in the Intensive Care Unit. Rev Esc Enferm USP[Internet]. 2016[cited 2018 Jul 31];50(5):816-22. Available from: http:// www. scielo.br/pdf/reeusp/v50n5/0080-6234-reeusp-50-05-0817.pdf

38. Farre AGMC, Pinheiro PNC, Vieira NFC, Gubert FA, Alves MDS, Monteiro EMLM. Adolescent health promotion based on community-centered arts education. Rev Bras Enferm [Internet]. 2018 [cited 2018 Jul 31];71(1):26-33.Available from: http://www.scielo.br/pdf/reben/v71n1/00347167-reben-71-01-0026.pdf 